\title{
Improved N-retention during L-Carnitine-Supplemented Total Parenteral Nutrition
}

\author{
H. Bohles M.D., ${ }^{*}$ H. Segerer, M.D., ${ }^{*}$ and W. Fekl, Ph.D. $\dagger$ \\ From the University Children's Hospital ${ }^{*}$ and the Institute for Experimental Nutrition + Erlangen, Federal Republic of Germany
}

\begin{abstract}
The influence of intravenously administered $\mathrm{L}_{r^{-}}$ carnitine on lipid- and nitrogen-metabolism was studied during total parenteral nutrition of piglets (mean weight $4077 \mathrm{~g} ; \mathrm{n}=$ 9). The infusion protocol was divided into three isocaloric and isonitrogenous 48 - $\mathrm{hr}$ periods. Amino acids $(3 \mathrm{~g} / \mathrm{kg}$ day) were administered throughout all three periods: $140 \mathrm{cal} / \mathrm{kg} /$ day were given as nonprotein calories, consisting only of glucose during period 1; during periods 2 and 3 , an amount of glucose calorically equivalent to $4 \mathrm{~g}$ fat $/ \mathrm{kg} /$ day was substituted with a lipid emulsion, and $\mathrm{L}$-carnitine $(1.5 \mathrm{mg} / \mathrm{kg} /$ day $)$ was added in period
\end{abstract}

3. Key parameters of fat- and nitrogen-metabolism were determined during the entire regime. Indirect calorimetry was performed and the respiratory quotient calculated during all three periods. The results demonstrate a more effective lipolysis and oxydation of fatty acids during L-carnitine supplementation. These changes produce an increased energy gain from exogenously administered fat and a distinct improvement in nitrogen balance. (Journal of Parenteral and Enteral Nutrition 8:9-13, 1983)
Infants switch their oxydative metabolism during the newborn period from the predominant use of carbohydrates to fat. ${ }^{1}$ In the oxydative degradation of fatty acids, carnitine is essential for the transfer of activated longchain fatty acids across the inner mitochondrial membrane. ${ }^{2}$ The capacity for carnitine synthesis is limited in premature infants, ${ }^{3}$ and decreased carnitine concentrations in serum and tissue can be demonstrated in newborns maintained on total parenteral nutrition (TPN).$^{4-6}$ Carnitine supplementation of infants should therefore be taken into consideration during TPN. However, from a general point of view, the metabolic effects of intravenously administered carnitine have to be clarified. The aim of the present study was to elucidate the effects of L-carnitine supplementation during TPN, using a piglet model.

\section{MATERIALS AND METHODS}

\section{Experimental Animals}

Nine male piglets (mini pigs, Gottingen, Federal Republic of Germany), with an average body weight of 4077 $\mathrm{g}$, were used in this study. This animal species appeared to be appropriate because of their metabolic similarities to infants. ${ }^{7,8}$ Their use was approved by the Government.

\section{Operations}

The external jugular vein was exposed by a lateral neck incision. A catheter was inserted into the right atrium of the heart and threaded subcutaneously to exit from the back of the neck. For continuous urine collection, a catheter was inserted into the bladder and secured by a purse-string suture. The urethra was ligated, and the animals were placed in hammocks after the opera-

Received for publication, September 23, 1982.

Accepted for publication, March 23, 1983.

Reprint requests to: Priv. Doz. Dr. H. Bohles, Universitatskinderklinik, 8520 Erlangen, Loschgestrasse 15, Federal Republic of Germany. tions (Fig. 1). They were unrestrained and could move about freely, but remained quiet without medical sedation, and received all nutrients via the central venous route. Urine was collected continuously and stored at $-20^{\circ} \mathrm{C}$ until analysis.

\section{Experimental Design}

The study commenced postoperatively, after a $48-\mathrm{hr}$ adaptation period, along the lines of the experimental design demonstrated in Figure 2. The TPN protocol was divided into three isocaloric and isonitrogenous $48-\mathrm{hr}$ periods: $3 \mathrm{~g} / \mathrm{kg}$ day of amino acids (Aminofusin pad 5\%) were administered throughout all three periods; $140 \mathrm{cal} /$ $\mathrm{kg} /$ day were given as nonprotein calories, consisting only of glucose during period 1 ; during periods 2 and 3 , an amount of glucose calorically equivalent to $4 \mathrm{~g}$ fat $/ \mathrm{kg} /$ day was substituted with a $20 \%$ lipid emulsion (Lipofundin $\mathrm{S} 20 \%)$. L-Carnitine $(1.5 \mathrm{mg} / \mathrm{kg} /$ day $)$ was added in period 3 .

\section{Indirect Calorimetry}

The animals were placed under a hood, as shown in Figure 1, and an airflow of about 1-2 liters/min was produced with a membrane pump. When compared with room air, differences in $\mathrm{O}_{2}$ and $\mathrm{CO}_{2}$ concentrations of about $1-1.5$ volume $\%$ were observed. Gas concentrations were measured continuously three times per day during 2-hr periods and the $\mathrm{CO}_{2} / \mathrm{O}_{2}$ ratios respiratory quotient (RQ) were calculated. The $\mathrm{O}_{2}$ and $\mathrm{CO}_{2}$ concentrations were determined using the paramagnetic properties of $\mathrm{O}_{2}$ and infrared absorption of $\mathrm{CO}_{2}$.

\section{Chemical Analysis}

Free fatty acids were measured according to the methodology of Trout et al, ${ }^{9}$ while $\beta$-OH--butyric acid was determined enzymatically according to the technique of Bergmeyer and Bernt. ${ }^{11}$ Both analyses were performed within 5 min of blood sampling. 


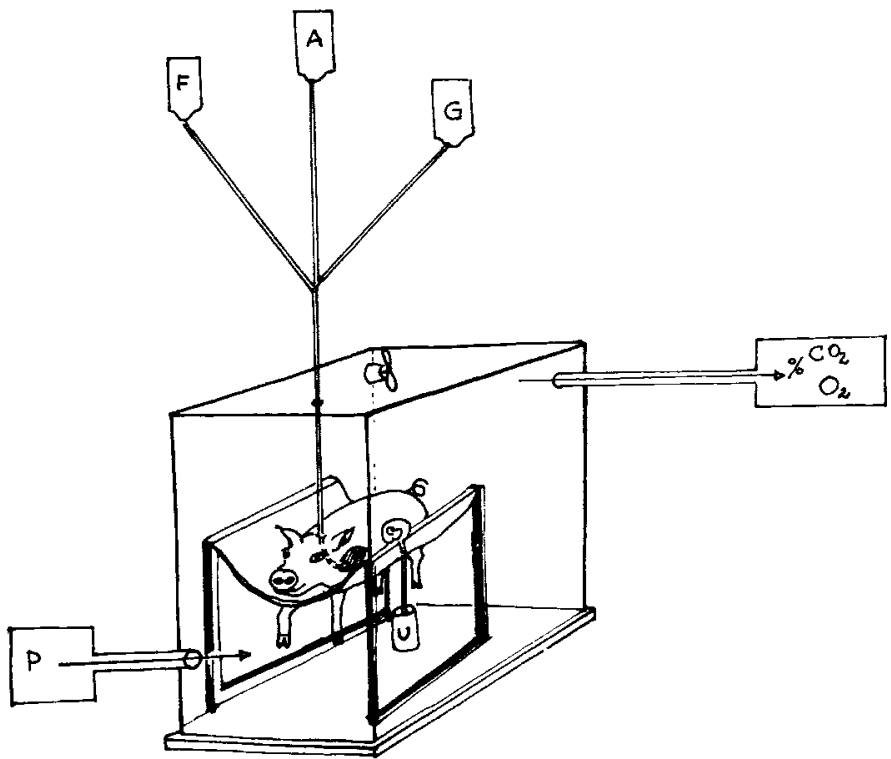

FIG. 1. Experimental design for TPN and indirect calorimetry. $P$, membrane pump (airflow: 1-2 liter/min). A, amino acid solution (5\%). $F$, lipid emulsion ( $20 \%)$. $G$, glucose solution. $U$, urine collection.
Triglycerides were assessed enzymatically (TestomarTriglyzeride, Behringwerke, Germany), and serum glycerol was quantitated using the test for triglycerides but without performing the initial alkaline hydrolysis. $\alpha$ $\mathrm{NH}_{3}$-nitrogen was measured in urine according to the procedure described by Pope and Stevens. ${ }^{11}$ Total urinary nitrogen was determined according to Kieldahl's method. ${ }^{12}$ Serum glucose, urea-N, lactate, and insulin were assessed with techniques routinely used in clinical laboratories. Carnitine was quantitated according to the methodology of McGarry and Foster ${ }^{13}$ before (free carnitine) and after alkaline hydrolysis (total carnitine). Acyl carnitine was calculated from differences between total and free carnitine.

\section{Statistical Analysis}

The data were analyzed statistically according to Wilcoxon's nonparametric test.

\section{RESULTS}

The metabolic changes during the individual infusion periods are listed in Table I. In period 1, the serum

EXPERIMENTAL DESIGN

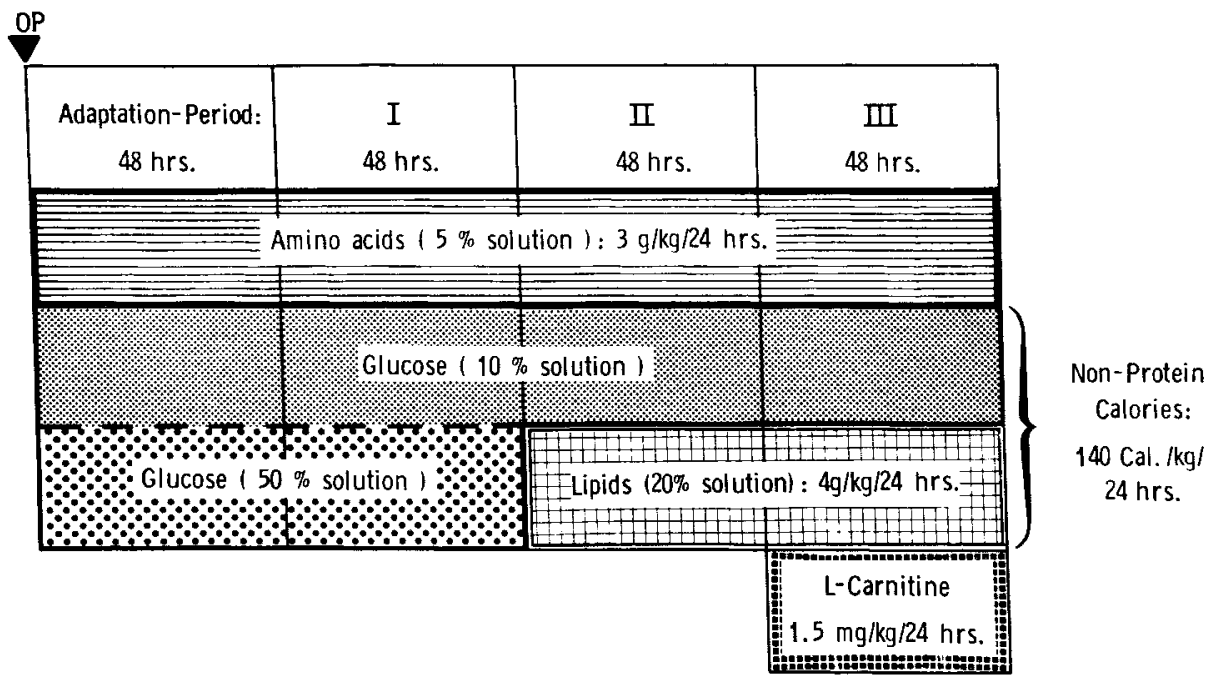

FIG. 2. Experimental design of TPN protocol.

TABLE I

Changes in metabolic parameters of serum and urine (mean $\pm 1 S D$ )

\begin{tabular}{|c|c|c|c|c|c|}
\hline Parameters & Period 1 & $\begin{array}{c}\text { Period } 1 \\
\text { vs } \\
\text { period } 2 \\
\end{array}$ & Period 2 & $\begin{array}{c}\text { Period } 2 \\
\text { us } \\
\text { period } 3 \\
\end{array}$ & Period 3 \\
\hline & & $p<$ & & $p<$ & \\
\hline Serum triglycerides $(\mathrm{mg} / \mathrm{dl})$ & $13.2 \pm 4.1$ & 0.01 & $33.9 \pm 1.9$ & 0.01 & $20.4 \pm 4.0$ \\
\hline $\begin{array}{l}\text { Serum free fatty acids ( } \mathrm{mEq} / \\
\text { liter) }\end{array}$ & $0.048 \pm 0.02$ & 0.01 & $0.20 \pm 0.06$ & 0.01 & $0.08 \pm 0.04$ \\
\hline Serum glycerol $(\mathrm{mg} / \mathrm{dl})$ & $0.54 \pm 0.40$ & NS & $0.85 \pm 0.56$ & NS & $1.65 \pm 1.4$ \\
\hline $\begin{array}{l}\text { Serum } \beta \text {-OH-butyric acid (mg/ } \\
\text { dl) }\end{array}$ & $0.20 \pm 0.07$ & NS & $0.18 \pm 0.08$ & 0.05 & $0.31 \pm 0.05$ \\
\hline $\begin{array}{l}\text { Urinary } \beta-\mathrm{OH} \text {-butyric acid }(\mathrm{mg} / \\
\text { day) }\end{array}$ & $1.02 \pm 0.27$ & 0.05 & $1.49 \pm 0.49$ & 0.05 & $2.62 \pm 0.94$ \\
\hline Serum total carnitine $(\mathrm{nmol} / \mathrm{ml})$ & $49.7 \pm 8.2$ & 0.01 & $71.1 \pm 6.8$ & 0.05 & $78.2 \pm 4.0$ \\
\hline Serum acyl carnitine $(\mathrm{nmol} / \mathrm{ml})$ & $39.9 \pm 8.6$ & 0.01 & $57.6 \pm 7.8$ & 0.01 & $69.5 \pm 2.3$ \\
\hline Urinary total carnitine $(\mu \mathrm{mol} /$ day $)$ & $70.8 \pm 1.6$ & 0.01 & $54.8 \pm 4.3$ & 0.01 & $105.2 \pm 8.3$ \\
\hline $\mathrm{RQ} \frac{\mathrm{JCO}_{2}}{\mathrm{JO}_{2}}$ & $0.97 \pm 0.05$ & 0.01 & $0.82 \pm 0.01$ & 0.01 & $0.76 \pm 0.03$ \\
\hline
\end{tabular}


triglyceride concentration was slightly below normal values for pigs, but showed an increase during infusion of the lipid emulsion in period 2. Free fatty acids also revealed elevated values, and the mean concentration of serum glycerol, the other split product of triglycerides, was augmented when periods 1 and 2 were compared. Lipid administration during period 2 elicited no rise in serum $\beta$-OH-butyric acid concentrations, but $\beta$-OH-butyric acid excretion in urine was accelerated.

The RQ reflected the oxydation of carbohydrates during period 1 and responded to the administration of lipids with a significant decrease in period 2. Although carnitine was not added in period 2 , the serum concentration of total carnitine showed a significant elevation which was mainly due to acyl carnitine. However, total urinary carnitine excretion fell after lipid administration and was enhanced after L-carnitine supplementation in period 3.

Period 3 witnessed a decrease of serum triglycerides and free fatty acids with an increase in the mean serum glycerol concentration. Ketone bodies, represented by $\beta$ $\mathrm{OH}$-butyric acid, were elevated in serum and urine during period 3. After carnitine was given, its total serum concentration rose significantly but only to a minor extent when compared with the elevation seen in period 2 . Again, this increment was mainly due to acyl carnitine.

A further decline of the $R Q$, in period 3 , demonstrated an augmentation of fatty acid oxydation. There was a significant correlation between serum acyl carnitine and serum $\beta$-OH-butyric acid as well as an inverse correlation between $\beta$-OH-butyric acid and free fatty acids $(\mathbf{r}=$ $-0.71 ; p<0.001)$.

A positive nitrogen balance was evident during all three periods of TPN. There was no significant difference between nitrogen retention in period $1(+0.35 \pm 0.11 \mathrm{~g}$ $\mathrm{N} /$ day) and period $2(+0.26 \pm 0.12 \mathrm{~g} \mathrm{~N} /$ day $)$. However, significantly more nitrogen was retained after carnitine supplementation in period $3(+0.85 \pm 0.36 \mathrm{~g} \mathrm{~N} /$ day; $p<$ 0.01 ) (Fig. 3). The nitrogen balance data were confirmed by changes in the amount of urea- $\mathrm{N}$ and $\alpha-\mathrm{NH}_{3}-\mathrm{N}$ excreted during period $3(p<0.01)$ (Fig. 4$)$.

The serum concentrations of glucose, lactate, insulin, and urea-N showed slight but nonsignificant alterations during the three infusion periods (Table II). However,

$[g N /$ day $] n=9$

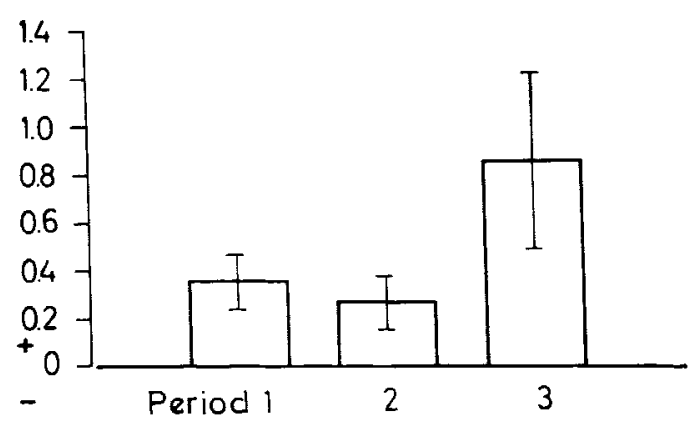

FIG. 3. Nitrogen balance data during the three infusion periods.

$$
\begin{aligned}
& \text { URINE } \\
& \alpha-\mathrm{NH}_{3}-\mathrm{N}[\mathrm{mg} / \text { day }]
\end{aligned}
$$
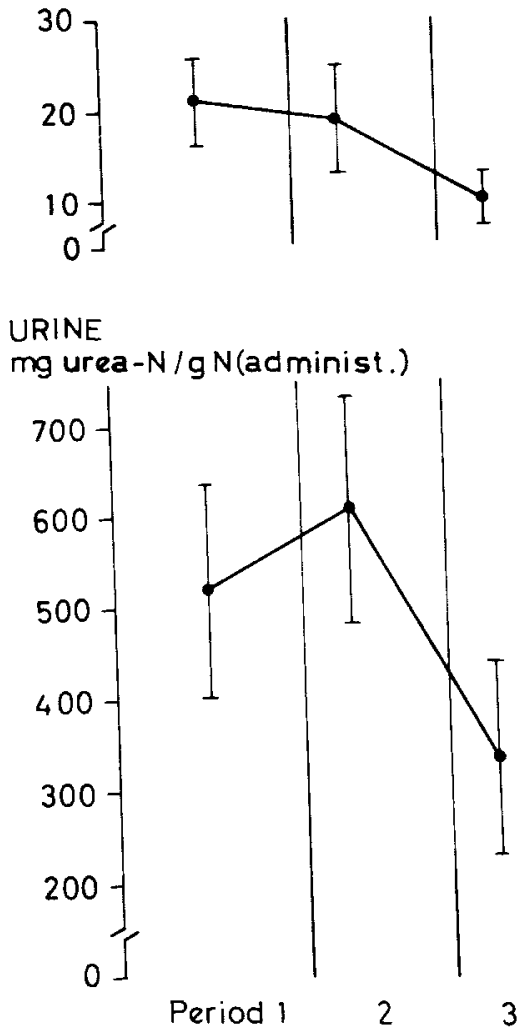

Fig. 4. Urinary urea- $\mathrm{N}$ and $\alpha-\mathrm{NH}_{3}-\mathrm{N}$-excretion (mean $\pm 1 \mathrm{SD}$ ).

TABLE II

Changes in metabolic serum parameters; the differences are statistically nonsignificant $($ mean $\pm 1 S D)$

\begin{tabular}{lccc}
\hline \multicolumn{1}{c}{ Serum parameters } & Period 1 & Period 2 & Period 3 \\
\hline Glucose $(\mathrm{mg} / \mathrm{dl})$ & $127 \pm 29$ & $110 \pm 21$ & $109 \pm 14$ \\
Lactate $(\mathrm{mg} / \mathrm{dl})$ & $5.7 \pm 3.0$ & $3.8 \pm 1.3$ & $3.9 \pm 1.0$ \\
Insulin $(\mathrm{uU} / \mathrm{ml})$ & $57.9 \pm 53$ & $23.9 \pm 13$ & $24.5 \pm 10$ \\
Urea nitrogen $(\mathrm{mg} / \mathrm{dl})$ & $4.9 \pm 3.9$ & $4.2 \pm 2.3$ & $3.3 \pm 1.4$ \\
\hline
\end{tabular}

the mean of the urea- $N$ concentration was decreased considerably during carnitine supplementation.

\section{DISCUSSION}

The observed metabolic differences between periods 1 and 2 reflect the transition to the infusion of lipids. The RQ proves a change from an almost exclusively carbohydrate oxydation to a mixed oxydative degradation of glucose and fat. $\beta$-oxydation was not effectively stimulated during period 2, as can be concluded from the increased concentrations of free fatty acids and the basically unchanged $\beta$-OH-butyric acid concentrations. ${ }^{3}$ This conclusion is supported by the inverse correlation between free fatty acids and $\beta-\mathrm{OH}$-butyric acid.

Without exogenous carnitine supplementation in period 2, there was an elevation of all serum carnitine fractions and a decline of total carnitine excretion in urine. A similar decrease could be observed by other 
investigators during the fasting state, ${ }^{14}$ during alimentation with a carnitine-deficient $\operatorname{diet}^{15}$ as well as during TPN of premature infants without carnitine supplementation. ${ }^{3-5}$ This phenomenon is generally interpreted as a regulatory action of the kidney to preserve carnitine stores. ${ }^{3.16,17}$ An increase of serum carnitine concentrations - which is mainly caused by acyl carnitine - was observed in fasting rats by Brass and Hoppel ${ }^{16}$ Frohlich et $\mathrm{al}^{14}$ reported comparable results for healthy fasting adults, while McGarry et al $^{18}$ demonstrated a rise in tissue carnitine concentrations during increased ketogenesis. In young infants, after a lipid infusion $(1 \mathrm{~g} / \mathrm{kg}$ over $4 \mathrm{hr}$ ), Schmidt-Sommerfeld and Penn ${ }^{6}$ noted unaltered serum concentrations of total carnitine with a change in the carnitine fractions in favor of acyl carnitine. Because of the short-term nature of the infusions, these results are not comparable to our long-term TPN data. However, the lack of an increase of total carnitine concentrations during short-term lipid infusion on the one hand and a significant elevation after long-term lipid application on the other may indicate the induction of de novo enzymatic synthesis of carnitine from lysine and methionine.

Augmented serum carnitine concentrations are believed to reflect improved carnitine availability, ${ }^{17}$ and serum acyl carnitine is of major importance in fatty acid oxydation. ${ }^{3}$ Acyl carnitine is increased in the case of high fatty acid turnover and ketogenesis ${ }^{19}$ and explains the correlation between acyl carnitine and $\beta-\mathrm{OH}$-butyric acid, ${ }^{6,16}$ which we could confirm.

Abnormally low serum carnitine concentrations have been observed in premature infants on carnitine-free TPN. ${ }^{3}$ This departure from our own results could be explained on the basis of a different situation of body carnitine stores on the one hand and immature synthesis in the premature infant on the other. ${ }^{20}$ During the period of exogenous carnitine supplementation, all measured metabolites of lipid metabolism indicated an enhancement of fatty acid oxydation, which could be proved by the further significant decrease of the RQ in period 3 . This change in the RQ corresponds to that observed by Kerr et $\mathrm{al}^{21}$ in a patient with systemic carnitine deficiency which decreased from 0.92 to 0.78 during carnitine supplementation. Similarly, an enhanced oxygen consumption could be demonstrated in fat tissue cells after the addition of carnitine. ${ }^{4}$ Novak et $\mathrm{al}^{22}$ documented a carnitine-induced increase of glycerol in the subcutaneous tissue of newborns. The fall of triglyceride concentrations, which occurred simultaneously to an increase of serum glycerol, indicates that lipolysis was enhanced. We, therefore, confirm the idea that, besides the stimulation of fatty acid oxydation, carnitine is involved in the regulation of lipolysis. ${ }^{4}$

The essential meaning of the changes in lipid metabolism, demonstrated after carnitine supplementation, is an improved energy gain from exogenously administered lipids, which is reflected in an improved nitrogen balance. The decreased excretion of urea- $\mathrm{N}$ and alpha- $\mathrm{NH}_{3}-\mathrm{N}$ after carnitine supplementation is a necessary equivalent of the changes in nitrogen balance. The slight fall in serum urea- $\mathrm{N}$ concentrations may also be indicative of better nitrogen utilization. Our animal study could objectively confirm the improvement of growth that hitherto was only empirically described. ${ }^{23,24}$

\section{CONCLUSIONS}

The present results suggest that $\mathrm{L}$-carnitine supplementation during TPN with lipid emulsions induces: (1) an increased lipolysis; (2) an enhanced oxydation of fatty acids; and (3) an improved nitrogen retention via a better energy supply from the infused lipids.

\section{REFERENCES}

1. Novak M, Monkus E: Metabolism of subcutaneous adipose tissue in the immediate postnatal period of human newborns. I. Devel opmental changes in lipolysis and glycogen content. Pediatr Res $6: 73-77,1972$

2. Fritz IB, Marquis NR: THe role of acylcarnitine esters and carnitine palmityl-transferase in the transport of fatty acyl-groups across mitochondrial membranes. Proc Nat Acad Sci USA 54:12261229, 1965

3. Penn D, Schmidt-Sommerfeld E, Wolf H: Carnitine deficiency in premature infants receiving total parenteral nutrition. Early Hum Dev 4:23-34, 1980

4. Penn D, Schmidt-Sommerfeld E, Pascu F: Decreased tissue carnitine concentrations in newborn infants receiving total parenteral nutrition. J Pediatr 98:976-978, 1981

5. Schiff D, Chan G, Seccombe D, et al: Plasma carnitine levels during intravenous feeding of the neonate. J Pediatr 95:1043-1046, 1979

6. Schmidt-Sommerfeld D, Penn D: Carnitine blood concentrations and fat utilization in parenterally alimented premature newborn infants. J Pediatr 100:260-264, 1982

7. Filer L, Owen GM, Fomon SJ: Effect of age, sex and diet on carcass composition of infant pigs. IN Swine in Biomedical Research. Bustad LK, McClellan RO (eds). Battelle Memorial Institute, 1966, p 141

8. Mount LE: Thermal and metabolic comparisons between the newborn pig and human infants. IN Swine in Biomedical Research. Bustad LK, McClellan RO (eds). Battelle Memorial Institute, 1966, p 501

9. Trout DL, Estes H, Friedberg SJ: Titration of free fatty acids of plasma: a study of current methods and a new modification. J Lipid Res 1:199-203, 1960

10. Bergmeyer HU, Bernt E: Enzymatische Bestimmung von Ketonkorpern im Blut. Enzym Biol Clin 5:65-67, 1965

11. Pope CG, Stevens MF: The determination of amino-nitrogen using a copper method. Biochem J 33:1070-1074, 1939

12. Determination of total nitrogen. IN Clinical Chemistry, Principles and Technics. Henry R, Cannon DC, Winkleman JW (eds). Harper \& Row, New York, 1974, pp 556-557

13. McGarry JD, Foster DW: An improved and simplified radioisotopic assay for the determination of free and esterified carnitine. J Lipid Res 17:277-281, 1976

14. Frohlich J, Seccombe DW, Hahn P, et al: The effect of fasting on free and esterified carnitine levels in human serum and urine: correlation with serum levels of free fatty acids and B-hydroxybutyrate. Metabolism 27:555-561, 1978

15. Mitchell M: Carnitine metabolism in human subjects. I. Normal metabolism. Am J Clin Nutr 31:293-296, 1978

16. Brass EP, Hoppel CL: Carnitine metabolism in the fasting rat. $J$ Biol Chem 253:2688-2693, 1978

17. Novak M, Monkus EF, Chung D, et al. Carnitine in the perinatal metabolism of lipids. I. Relationship between maternal and fetal plasma levels of carnitine and acyl carnitines. Pediatrics 67:95100,1981

18. McGarry JD, Robles-Valdes C, Foster DW: Role of carnitine in hepatic ketogenesis. Proc Nat Acad Sci 72:4385-4388, 1975

19. Seccombe DW, Hahn P, Novak M: The effect of diet and development on blood levels of free and esterified carnitine in the rat. Biochem Biophys Acta 528:483-487, 1978 
20. Rebouche $\mathrm{CJ}$ : Comparative aspects of carnitine biosynthesis in microorganisms and mammals with attention to carnitine synthesis in man. IN Carnitine Biosynthesis, Metabolism and Functions. Frenkel RA, McGarry JD (eds). Academic Press, New York, 1980, p 57

21. Kerr D, Shurin S, Tserng K, et al: Metabolic effects of treatment of systemic carnitine deficiency. Pediatr Res 15:633, 1981

22. Novak M, Penn-Walker D, Hahn P, et al: Effect of carnitine on lipolysis in subcutaneous adipose tissue of newborns. Biol Neonate
$25: 85-89,1975$

23. Alexander K. Peeters H, Vuylsteke P: Activitê clinique et metabolique de la carnitine chez l'enfant. IN Proteides of the Biological Fluids. Proceedings of the Sixth Colloquium, Bruges, Elsevier Publishing Co., Amsterdam, 1958, p 306

24. Borniche $\mathrm{P}$, Canlorbe $\mathrm{P}$ : Action clinique et humorale de la carnitine dans les syndromes de denutrition post-infectieux de l'enfance. Clin Chim Acta 5:171-176, 1960

\section{Announcements}

\section{Meetings}

The 8th World Congress of the Collegium Internationale Chirurgiae Digestivae will be held on September 11-14, 1984 in Amsterdam, the Netherlands. The program will include panel sessions, poster sessions, and workshops with free papers, movies, and video shows on any subject in gastrointestinal surgery. Commercial exhibits are invited. For information, contact: Henk Haarman, M.D., Secretary General, 8th World Congress CICD, P/o Congress Bureau, QLT Convention Services, Keizersgracht 792, 1017 EC Amsterdam, The Netherlands.

The Second Work Conference and Seminar on Clinical Nutrition will be offered on April 9-13, 1984, at Memorial Sloan-Kettering Cancer Center. The course is designed for clinical dietitians and will include an overview of and update on various aspects of clinical nutrition. The format of lectures, demonstrations, roundtable sessions, workshops, and discussion groups will provide maximal opportunity for interaction between the faculty and participants. Conference Director: Maurice E. Shils. For information, contact: Abby Bloch, Memorial Sloan-Kettering Cancer Center, Box 279, 1275 York Avenue, New York, NY 10021.

An Update in Nutrition and Gastroenterology will be held April 5-6, 1984, at the New England Deaconess Hospital in Boston, MA. The program is being sponsored by the Department of Dietetics. For informa- tion, contact: Lydia Kuchun, NEDH, 185 Pilgrim Road, Boston, MA 02115, (617) 732-8171.

The Third Annual Contemporary Nutrition Practice Seminar on Computers: Application to Dietetics will be held Friday, March 16, 1984, at Holiday Inn Airport, 4500 Cypress, Tampa, FL. The program is sponsored by Nutrition Services, Tampa General Hospital. Registration fee: $\$ 45.00$ (includes breakfast, lunch, educational materials). For information, contact: Kim Valldejuli, R.D., Tampa General Hospital Nutrition Services, Davis Island, Tampa, FL 33606, (813) 251-7215.

\section{Educational Opportunities}

American Board of Nutrition Examination. Eligible individuals (Ph.D., M.D., or equivalent) with appropriate nutrition backgrounds are invited and encouraged to file applications to take the qualifying examination to become a Diplomate of the American Board of Nutrition (ABN). The exam will be administered on May 2,1984 , just prior to the national clinical meetings, in the Sheraton Washington Hotel. The deadline for receipt of completed applications, transcripts of academic records and sponsor letters is January 31, 1984. Application forms, Statement of Philosophy, Examination Scope and Guidelines for taking the ABN examination are available upon request. For information, write: American Board of Nutrition, Room B-25, 9650 Rockville Pike, Bethesda, MD 20814, (301) 530-7110. 